\title{
MAIN TRENDS IN THE DEVELOPMENT OF RUSSIAN LAW ON NON-PROFIT ORGANIZATIONS
}

\author{
ALEXEI AVTONOMOV, \\ Institute of International Law and Economics named after A. Griboedov \\ (Moscow, Russia) \\ VLADISLAV GRIB, \\ MGIMO University (Moscow, Russia)
}

https://doi.org/10.21684/2412-2343-2020-7-3-81-103

The article is a comparative study of legal regulation on non-profits in the Russian Federation by federal law, including the Constitution, federal statutes, decrees of the President of the Russian Federation, resolutions of the Government and Constitutional Court rulings in connection with certain international legal acts dealing with the right to association, and by the law of the constituent entities of the Russian Federation. The main stages of the development of the law on non-profits both at the federal level and at the level of the constituent entities of the Russian Federation, as well as the main trends in the development of non-profit law in modern Russia, are explored.

Keywords:non-profitlaw;not-for-profitorganization; public association; non-governmental organization; constitutional right to association; federal regulation of non-profits in Russia; regional regulation of non-profits in the constituent entities of the Russian Federation; socially oriented organizations.

Recommended citation: Alexei Avtonomov \& Vladislav Grib, Main Trends in the Development of Russian Law on Non-Profit Organizations, 7(3) BRICS Law Journal 81-103 (2020).

\section{Table of Contents}

\section{Federal Legislation}

2. Legislation of the Constituent Entities of the Russian Federation 


\section{Federal Legislation}

In the present study, the terms "non-profit organization" (NPO) and "non-governmental organization" (NGO) are used as notions with a similar meaning, or "roughly synonymous,"' which is in line with the commonly shared understanding of scholars and practitioners, ${ }^{2}$ while "public association" is one of the forms of non-governmental or not-for-profit organizations.

At the federal level, the regulation of non-profit organizations is based on the right of association enshrined in the Constitution of the Russian Federation (Art. 30):

1. Everyone has the right to association, including the right to create trade unions to protect their interests. Freedom of activity of public associations is guaranteed.

2. No one may be compelled to join or remain in any association. ${ }^{3}$

The wording of the right to association in the Russian Constitution is consistent with the wording contained in international legal acts, including the special mention of the right to create trade unions as a right included in the right to association. Thus, Article 20 of the Universal Declaration of Human Rights reads:

(1) Everyone has the right to freedom of peaceful assembly and association.

(2) No one may be compelled to belong to an association. ${ }^{4}$

The Universal Declaration of Human Rights is, of course, an authoritative document, but it was adopted in the form of a resolution of the U.N. General Assembly, therefore officially it is of a recommendatory nature.

Yet, there are international legal acts of a binding nature for their participants that enshrine the right to association. Thus, in the most general form, the right to association is established by Article 22 of the International Covenant on Civil and Political Rights. Part 1 of this Article contains the wording of the right of association as follows:

Everyone shall have the right to freedom of association with others, including the right to form and join trade unions for the protection of their interests..$^{5}$

\footnotetext{
The Palgrave Handbook of Volunteering, Civic Participation, and Nonprofit Associations 93 (D.H. Smith et al. (eds.), Basingstoke: Palgrave Macmillan, 2016).

2 Id. at 93-94.

3 Конституция Российской Федерации [Constitution of the Russian Federation] 21 (Moscow: Yuridicheskaya literatura, 2018).

4 Universal Declaration of Human Rights, United Nations (Jul 5, 2020), available at https://www.un.org/ en/universal-declaration-human-rights/.

5 The Core International Human Rights Treaties 33 (New York; Geneva: United Nations, 2006).
} 
Freedom of association, as one knows, implies the right to form associations, join associations and leave them. At the same time, the U.N. Human Rights Committee (which exists in accordance with the Covenant under consideration) in its Views of 31 October 2006, following consideration of Communication No. 1274/2004"Viktor Korneenko et al. v. Belarus,"

observes that the right to freedom of association relates not only to the right to form an association, but also guarantees the right of such an association freely to carry out its statutory activities. ${ }^{6}$

However, the establishment of the right to association does not mean the absence of restrictions on this right.

Part 2 of Article 22 stipulates:

No restrictions may be placed on the exercise of this right other than those which are prescribed by law and which are necessary in a democratic society in the interests of national security or public safety, public order (ordre public), the protection of public health or morals or the protection of the rights and freedoms of others. This article shall not prevent the imposition of lawful restrictions on members of the armed forces and of the police in their exercise of this right.?

Thus, the International Covenant on Civil and Political Rights permits legislative restriction of the rights established by the article of this Covenant, but links such restrictions to the existence of democracy, and also sets the limits within which restrictions and rights are possible and permissible.

This Covenant shows the interconnectedness of various international legal acts on the right of association. This follows, in particular, from part 3 of Article 22 of the Covenant:

Nothing in this article shall authorize States Parties to the International Labour Organization Convention of 1948 concerning Freedom of Association and Protection of the Right to Organize to take legislative measures which would prejudice, or to apply the law in such a manner as to prejudice, the guarantees provided for in that Convention. ${ }^{8}$

It is not by chance that the Covenant refers to this very ILO 1948 Convention, as by the time of the drafting and adoption of the Covenant the mentioned Convention

\footnotetext{
6 U.N. Doc.CCPR/C/88/D/1274/2004, 10 November 2006, para. 7.2.

The Core International Human Rights Treaties, supra note 5.

Id.
} 
was the only binding international document dealing specially and exclusively with associations although acting within a narrow field. At the same time, a competent ILO body

has considered it appropriate to emphasize the importance to be attached to the basic principles set out in the Universal Declaration of Human Rights, considering that their infringement can adversely affect the free exercise of trade union rights. ${ }^{9}$

A number of international legal acts regulate certain aspects of the right to association, and in general Russian legislation complies with international standards. But the study of the implementation of international provisions in Russian legal acts is not part of the task of this work.

Along with the right to association, some other constitutional human rights are also important for the creation and active work of non-profit organizations, including the right of everyone, as established in part 1 of Article 34 of the Constitution of the Russian Federation, "to free use of one's abilities and property for entrepreneurial and other economic activities not prohibited by law."10 In addition, according to part 2 of the same Article, "economic activities aimed at monopolization and unfair competition are not allowed."' Part 2 of Article 34 is directed, as follows from the text itself, to regulate, first of all, entrepreneurial activity and to protect competition in the course of its implementation. As for part 1 of this Article, it covers a much wider range of activities with its regulation, obviously, not limited solely to entrepreneurial activity. It is clear that by creating a non-profit organization or working in one, a person realizes his/her right to freely use his/her abilities and property for economic activities, which are not prohibited by law, since the activity of non-governmental non-profit organizations has, to one degree or another, an economic component that is not, however, entrepreneurial, i.e. aimed at making a profit.

Article 13(4) of the Constitution of the Russian Federation provides for the equality of public associations before the law. Part 3 of the same Article points out that the "Russian Federation recognizes political diversity and a multi-party system.". ${ }^{2}$

Part 1 of Article 36 raises to the constitutional level the consolidation of the right of private ownership of land:

Citizens and their associations have the right to have land in private ownership. $^{13}$

\footnotetext{
Freedom of Association: Digest of Decisions and Principles of the Freedom of Association Committee of the Governing Body of the ILO 13 ( $4^{\text {th }}$ ed., Geneva: ILO, 1996).

10 Constitution of the Russian Federation, supra note 3, at 23.

11 Id.

12 Id. at 13 .

13 Id. at 24.
} 
It is true that for the vast majority of not-for-profit associations this right is irrelevant and exists only as a potential opportunity, since the presence of land ownership is unusual for the vast majority of non-profit associations. At the same time, a certain number of partnerships of homeowners and other associations of homeowners have managed to obtain ownership of adjoining (to blocs of apartments) territories, as well as land under buildings; there is also land owned by various not-for-profit summer cottages, horticultural and vegetable garden associations as well as communities of small in number indigenous peoples.

Article 55(3) of the Constitution of the Russian Federation contains the general terms of possible restrictions of rights and freedoms, including the right of association:

The rights and freedoms of man and citizen may be limited by federal law only to the extent necessary to protect constitutional order, morality, health, rights and lawful interests of other persons, national defense and state security. ${ }^{14}$

Thus, human rights and freedoms may be limited by federal law, while it is clear that they cannot be limited by a decree of the President of the Russian Federation, a resolution of the Government of the Russian Federation, the law of a constituent entity of the Russian Federation or a municipal act, among other actions. However, from the wording of the cited constitutional provision it is not clear whether it is acceptable to restrict rights and freedoms (in particular, the right to association) by a federal constitutional law, or adoption of a federal constitutional law, meaning restrictions on human rights and freedoms must be accompanied by the adoption of a federal law that complements the federal constitutional law in terms of the introduction of these restrictions. When adopting a federal law that formulates restrictions on human rights and freedoms (in this case, the right to association), the legislator must check whether it goes beyond the goals that limit possible restrictions on human rights. If it does, then restrictions on human rights (in this case, restrictions on the right to association) should be considered unconstitutional.

Along with the general conditions that should not be violated when restricting human rights, the Constitution of the Russian Federation, in Article 56, contains limits on possible restrictions on human rights when a state of emergency is introduced:

1. In a state of emergency, in order to ensure the safety of citizens and to protect the constitutional order, certain restrictions on rights and freedoms may be established in accordance with federal constitutional law, indicating their limits and duration.

\footnotetext{
14 Constitution of the Russian Federation, supra note 3, at 35.
} 
2. A state of emergency on the whole territory of the Russian Federation and in its certain areas may be introduced in the presence of circumstances and in the manner established by a federal constitutional law.

3. The rights and freedoms provided for in Articles 20, 21, 23(1), 24, 28, $34(1), 40(1), 46-54$ of the Constitution of the Russian Federation shall not be subject to restriction. ${ }^{15}$

We draw attention to the fact that Article 30, which proclaims the right to association, was not included in the number of "protected" articles when a state of emergency is introduced, but part 1 of Article 34, which contains provisions that are relevant for the creation and activities of non-governmental organizations, is protected from restrictions in the course of a state of emergency.

Part 5 of Article 13 of the Constitution is directly devoted to the criteria according to which the right to association may be restricted:

The creation or activities of public associations whose goals or actions are aimed at forcibly changing the foundations of the constitutional order and at violating the integrity of the Russian Federation, undermining the security of the State, forming armed groups, inciting social, racial, national and religious hatred is prohibited. ${ }^{16}$

Federal laws relating to not-for-profit organizations and based on the provisions of the new Constitution began to be developed immediately after its adoption. The first part of the Civil Code of the Russia Federation contained provisions on non-commercial organizations (using the terminology of the Civil Code) as legal persons, though not elaborated very well especially in comparison with provisions on commercial organizations/legal persons; it entered into force on 1 January 1995. ${ }^{17}$ In that same year, the following statutes took effect: the Federal Law on Public Associations $^{18}$ (permitting the formal existence of public associations without any registration), the Federal Law on Support of Youth and Children's Public Associations ${ }^{19}$

15 Constitution of the Russian Federation, supra note 3, at 35.

16 Id. at 13.

17 Гражданский кодекс Российской Федерации (часть первая) от 30 ноября 1994 г. № 51-Ф3 // СПС «КонсультантПлюс» [Civil Code of the Russian Federation (Part One) of 30 November 1994 No. 51-FZ, SPS "ConsultantPlus"] (Jul 5, 2020), available at http://www.consultant.ru/document/ cons_doc_LAW_5142/.

18 Федеральный закон от 19 мая 1995 г. № 82-Ф3 «Об общественных объединениях» // СПС «КонсультантПлюс» [Federal Law No. 82-FZ of 19 May 1995. On Public Associations, SPS "ConsultantPlus"] (Jul 5, 2020), available at http://www.consultant.ru/document/cons_doc_LAW_6693/.

19 Федеральный закон от 28 июня 1995 г. № 98-Ф3 «О государственной поддержке молодежных и детских общественных объединений» // СПС «КонсультантПлюс» [Federal Law No. 98-FZ of 28 
and the Federal Law on Charitable Activity and Charitable Organizations. ${ }^{20}$ In 1996, the Federal Law on Non-Commercial Organizations, ${ }^{21}$ the Federal Law on Trade Unions, their Rights and Guarantees of their Activity, ${ }^{22}$ the Federal Law on National Cultural Autonomy (dealing with public associations, active in the ethno-cultural sphere, and their unions ${ }^{23}$ entered into force. In 1997, the Federal Law on the Freedom of Consciousness and Religious Organizations ${ }^{24}$ was enacted. In 1999, the Federal Law on Guarantees of Russian Federation Small in Number Indigenous Peoples Rights (regulating, among other issues, communities of mentioned peoples as non-profits) ${ }^{25}$ was approved, and in 2000 the Federal Law on General Principles of Organization of Communities of Small in Number Indigenous Peoples of Siberia and the Far East of the Russian Federation ${ }^{26}$ was adopted. These are only some of the acts regulating different aspects of not-forprofit organizations establishment and operation. Thus, certain provisions dealing

June 1995. On State Support of Youth and Children's Public Associations, SPS "ConsultantPlus"] (Jul 5, 2020), available at http://www.consultant.ru/document/cons_doc_LAW_7041/.

20 The title of this Federal Law was changed along with certain amendments in 2018 to the Federal Law on Charitable Activity and Volunteering. Федеральный закон от 11 августа 1995 г. № 135-Ф3 «О благотворительной деятельности и добровольчестве (волонтерстве)» // СПС «КонсультантПлюс» [Federal Law No. 135-FZ of 11 August 1995. On Charitable Activity and Volunteering, SPS "ConsultantPlus"] (Jul 5, 2020), available at http://www.consultant.ru/document/cons_doc_LAW_7495/ f4ec47e4f44b82409fe6ea3f417fbc043b5b418d/.

21 Федеральный закон от 12 января 1996 г. № 7-Ф3 «О некоммерческих организациях» // СПС «КонсультантПлюс» [Federal Law No. 7-FZ of 12 January 1996. On Non-Commercial Organizations, SPS "ConsultantPlus"] (Jul 5, 2020), available at http://www.consultant.ru/document/cons_doc_ LAW_8824/.

22 Федеральный закон от 12 января 1996 г. № 10-Ф3 «О профессиональных союзах, их правах и гарантиях деятельности» // СПС «КонсультантПлюс» [Federal Law No. 10-FZ of 12 January 1996. On Trade Unions, their Rights and Guarantees of their Activity, SPS "ConsultantPlus"] (Jul 5, 2020), available at http://www.consultant.ru/document/cons_doc_LAW_8840/.

23 Федеральный закон от 17 июня 1996 г. № 74-Ф3 «О национально-культурной автономии» // СПС «КонсультантПлюс» [Federal Law No. 74-FZ of 17 June 1996. On National Cultural Autonomy, SPS "ConsultantPlus"] (Jul 5, 2020), available at http://www.consultant.ru/document/cons_doc_ LAW_10722/.

24 Федеральный закон от 26 сентября 1997 г. № 125-Ф3 «О свободе совести и о религиозных объединениях» // СПС «КонсультантПлюс» [Federal Law No. 125-FZ of 26 September 1997. On the Freedom of Consciousness and Religious Organizations, SPS "ConsultantPlus"] (Jul 5, 2020), available at http://www.consultant.ru/document/cons_doc_LAW_16218/.

25 Федеральный закон от 30 апреля 1999 г. № 82-Ф3 «О гарантиях прав коренных малочисленных народов Российской Федерации» // СПС «КонсультантПлюс» [Federal Law No. 82-FZ of 30 April 1999. On Guarantees of Russian Federation Small in Number Indigenous Peoples Rights, SPS "ConsultantPlus"] (Jul 5, 2020), available at http://www.consultant.ru/document/cons_doc_LAW_22928/.

26 Федеральный закон от 20 июля 2000 г. № 104-Ф3 «Об общих принципах организации общин коренных малочисленных народов Севера, Сибири и Дальнего Востока Российской Федерации» // СПС «КонсультантПлюс» [Federal Law No. 104-FZ of 20 July 2000. On General Principles of Organization of Communities of Small in Number Indigenous Peoples of Siberia and the Far East of the Russian Federation, SPS "ConsultantPlus"] (Jul 5, 2020), available at http://www.consultant.ru/document/ cons_doc_LAW_27908/. 
with non-profits were introduced in taxation laws. At the end of the 1990s, taxation laws were codified: Part 1 of the Taxation Code of the Russian Federation ${ }^{27}$ entered into force on 1 January 1999, and its Part $2^{28}$ on 1 January 2001, while certain chapters of Part 2 dedicated to specific taxes were given effect step by step between 1 January 2001 and 1 January 2005. In the second half of the 1990s, various regulations and rules dealing with not-for-profit organizations were adopted by the Government (executive body) and some ministries, first of all by the Ministry of Justice on the basis of the federal laws mentioned earlier.

So, the first stage of the development of federal legislation on not-for-profit organizations in modern Russia might be characterized as the legal institutionalization of non-profits and lasted from the mid-1990s, beginning with the entry into force of the Constitution, to the beginning of the 2000s, ending with the adoption of the Federal Law on Political Parties ${ }^{29}$ (2001). However, after the completion of this stage the mentioned, and other, acts continued to be amended, and legislation in general in this field developed.

The second stage of the development of federal legislation on not-for-profit organizations dealt with the legal institutionalization of the interaction between non-profits, public authorities (State bodies and local governments) and commercial companies. This stage began at the turn of the century and lasted around ten years. Thus, on 1 January 2000 the Russian Budgetary Code ${ }^{30}$ took effect and its Article 78, devoted to subsidies and subventions, provided for grants which might be given to legal entities. That provision served as the basis for State and municipal grants to nongovernmental not-for-profit organizations. Later, in 2007, Article 78 of the Budgetary Code was amended (the amendment entered into force on 1 January 2008), the word "grants" was excluded from the text, while the possibility of providing subsidies and subventions to non-governmental not-for-profit organizations remained. Provisions of the Budgetary Code (before and after 2008) allow public authorities and civil society institutions to cooperate when goals of authorities and certain social groups coincide and might be achieved as a result of projects prepared and realized by non-governmental non-profit organizations, expressing the interests of respective

27 Налоговый кодекс Российской Федерации (часть первая) от 31 июля 1998 г. № 146-Ф3 //СПС «КонсультантПлюс» [Tax Code of the Russian Federation (Part One) of 31 July 1998 No. 146-FZ, SPS "ConsultantPlus"] (Jul 5, 2020), available at http://www.consultant.ru/document/cons_doc_LAW_19671/.

28 Налоговый кодекс Российской Федерации (часть вторая) от 5 августа 2000 г. № 117-ФЗ //СПС «КонсультантПлюс» [Tax Code of the Russian Federation (PartTwo) of 5 August 2000 No. 117-FZ, SPS "ConsultantPlus"] (Jul 5, 2020), available at http://www.consultant.ru/document/cons_doc_LAW_28165/\#dst0.

29 Федеральный закон от 11 июля 2001 г. № 95-Ф3 «О политических партиях» // СПС «КонсультантПлюс» [Federal Law No. 95-FZ of 11 July 2001. On Political Parties, SPS "ConsultantPlus"] (Jul 5, 2020), available at http://www.consultant.ru/document/cons_doc_LAW_32459/.

30 Бюджетный кодекс Российской Федерации от 31 июля 1998 г. № 145-Ф3 // СПС «КонсультантПлюс» [Budget Code of the Russian Federation of 31 July 1998 No. 145-FZ, SPS "ConsultantPlus"] (Jul 5, 2020), available at http://www.consultant.ru/document/cons_doc_LAW_19702/. 
social groups, and funded from a budget (federal, regional or municipal). In 2004, the Decree of the President of the Russian Federation on the Council for the Development of Civil Society and Human Rights ${ }^{31}$ was issued. In 2005, the Federal Law on the Civic Chamber of the Russian Federation ${ }^{32}$ was enacted and the Civic Chamber began to function in 2006. The mentioned Council and Civic Chamber, each of them having its own mode of membership manning, functions and ways and methods of work, constitute forms of interaction between State bodies and civil society institutions.

Although each of the stages is characterized in its own way, this characteristic shows the priority direction of the development of legislation; however, other legislation, being the priority at some other stage, nevertheless develops at other stages too. For example, the Civil Code paragraphs dealing with non-commercial organizations were completely revised in 2014 within a global reform of the Civil Code of the Russian Federation. ${ }^{33}$ But this revision did not impact fully the characteristic of the stage of the development of federal legislation on not-for-profit organizations, because, firstly, the reform was motivated predominantly by the necessity to bring legal formulas in line with the realities and needs of civil turnover, taking into account issues of application of the law and judicial practice, and the provisions on non-profits seemed to be not the main question, which was considered to be the requirement for amendments; secondly, the original version of the Civil Code provisions on nonprofits was not elaborated as thoroughly as the majority of other provisions due to lack of experts in non-profit law among the drafters of the Civil Law that gave rise to the need for the improvement of those provisions; and, thirdly, it was a codification of changes in legislation on non-profits, which had been accumulating over the course of the previous twenty years.

In the third stage of the development of federal legislation on not-for-profit organizations lawmakers have focused their efforts on the incentives and mechanisms of non-governmental not-for-profit organizations' involvement in providing social services. This stage began in 2010 with the entry into force of the Federal Law on Amendments to Certain Legislative Acts of the Russian Federation Concerning the

31 Указ Президента РФ от 6 ноября 2004 г. № 1417 «О Совете при Президенте Российской Федерации по содействию развитию институтов гражданского общества и правам человека» // СПС «КонсультантПлюс» [Decree of the President of the Russian Federation No. 1417 of 6 November 2004. On the Council Under the President of the Russian Federation to Promote the Development of Civil Society Institutions and Human Rights, SPS "ConsultantPlus"] (Jul 5, 2020), available at http://www.consultant. $\mathrm{ru} /$ cons/cgi/online.cgi?req=doc\&base $=E X P \& n=504107 \# 09320602842176777$.

32 Федеральный закон от 4 апреля 2005 г. № 32-Ф3 «Об Общественной палате Российской Федерации» // СПС «КонсультантПлюс» [Federal Law No. 32-FZ of 4 April 2005. On the Public Chamber of the Russian Federation, SPS "ConsultantPlus"] (Jul 5, 2020), available at http://www.consultant.ru/document/ cons_doc_LAW_52651\%.

33 ГК РФ § 6. Некоммерческие корпоративные организации // СПС «КонсультантПлюс» [Civil Code of the Russian Federation, § 6. Non-Commercial Corporate Organizations, SPS "ConsultantPlus"] (Jul 5, 2020), available at http://www.consultant.ru/document/cons_doc_LAW_5142/07c9d84e3be048dd a7eb4c0d79bb689b90a0fbdb/. 
Support of Socially Oriented Non-Commercial Organizations. ${ }^{34}$ The notion of a socially oriented not-for-profit organization was introduced into Russian legislation specially to cluster a type of socially oriented non-profits that provide social services and as such may count on State or municipal budgetary support of their activities. This federal law was supplemented by the 2013 Federal Law on Amendments to the Federal Law on Non-Commercial Organizations (concerning contracts on providing goods and services for State and municipal needs $)^{35}$ and by the 2013 Federal Law on the Contract System in the Field of Procurement of Goods, Work, Services to Ensure State and Municipal Needs..$^{36}$ On 1 January 2015, the Federal Law on the Basics of Social Services for Citizens in the Russian Federation ${ }^{37}$ entered into force and prescribed that non-governmental non-profits might provide social services on an equal basis with State and municipal organizations (previously such equality legally and practically had not existed). In 2016, Article 34.4 was introduced in the Federal Law on NonCommercial Organizations and entitled "Recognition of a Socially-Oriented NonCommercial Organization as a Performer of Socially Useful Services" (it took effect on 1 January 2017). Later in 2016, the Russian Government (the executive body) adopted Resolution No. 1096 on Approval of the List of Socially Useful Services and Criteria for Assessing the Quality of their Provision..$^{38}$ In 2017 the Resolution of the Government of the Russian Federation No. 89 on the Register of Non-Commercial Organizations-

34 Федеральный закон от 5 апреля 2010 г. № 40-Ф3 «О внесении изменений в отдельные законодательные акты Российской Федерации по вопросу поддержки социально ориентированных некоммерческих организаций» // СПС «КонсультантПлюс» [Federal Law No. 40-FZ of 5 April 2010. On Amendments to Certain Legislative Acts of the Russian Federation Concerning the Support of Socially Oriented Non-Commercial Organizations, SPS "ConsultantPlus"] (Jul 5, 2020), available at http://www.consultant.ru/document/cons_doc_LAW_99113/.

35 Обзор изменений Федерального закона от 12 января 1996 г. № 7-Ф3 «О некоммерческих организациях» // СПС «КонсультантПлюс» [Review of amendments to the Federal Law of 12 January 1996 No. 7-FZ "On Non-Commercial Organizations," SPS "ConsultantPlus"] (Jul 5, 2020), available at http://www.consultant.ru/document/cons_doc_LAW_76388/551aca20d04948601ecc90a4ca6d33 $133 \mathrm{cbbbedb} /$.

36 Федеральный закон от 5 апреля 2013 г. № 44-Ф3 «О контрактной системе в сфере закупок товаров, работ, услуг для обеспечения государственных и муниципальных нужд» // СПС «КонсультантПлюс» [Federal Law No. 44-FZ of 5 April 2013. On the Contract System in the Field of Procurement of Goods, Work, Services to Ensure State and Municipal Needs, SPS "ConsultantPlus"] (Jul 5, 2020), available at http://www.consultant.ru/document/cons_doc_LAW_144624/.

37 Федеральный закон от 28 декабря 2013 г. № 442-Ф3 «Об основах социального обслуживания граждан в Российской Федерации» // СПС «КонсультантПлюс» [Federal Law No.442-FZ of 28December 2013. On the Basics of Social Services for Citizens in the Russian Federation, SPS "ConsultantPlus"] (Jul 5, 2020), available at http://www.consultant.ru/document/cons_doc_LAW_156558/.

38 Постановление Правительства Российской Федерации от 27 октября 2016 г. № 1096 «Об утверждении перечня общественно полезных услуг и критериев оценки качества их оказания» // СПС «КонсультантПлюс» [Decree of the Government of the Russian Federation No. 1096 of 27 October 2016. On Approval of the List of Socially Useful Services and Criteria for Assessing the Quality of their Provision, SPS "ConsultantPlus"] (Jul 5, 2020), available at http://www.consultant.ru/document/ cons_doc_LAW_206497/. 
Performers of Socially Useful Services ${ }^{39}$ was adopted. Organizations included in the register receive State and municipal support and a number of advantages. In 20192020 , work is underway on a draft federal law on State and municipal orders which is aimed at deepening the regulation of the participation of non-profit organizations in the provision of social services. Therefore, the third stage of the development of federal legislation on not-for-profit organizations is still ongoing.

In the second decade of the $21^{\text {st }}$ century State control over not-for-profit organizations has been strengthened. Thus, in 2002 the notion of "an organization executing functions of a foreign agent" was introduced into Russian legislation in the form of an amendment, in particular, to the Federal Law on Non-Commercial Organizations (part 6 of Article 2), which was modified in 2016 by a new amendment. In 2015, the notion of "an undesirable organization," concerning foreign and international organizations acting in the Russian Federation through their affiliations, was established by the Federal Law on Amendments to Certain Legislative Acts of the Russian Federation..$^{40}$ The question of the constitutionality of the legislative definition of "an organization acting as a foreign agent" and the application of the relevant legislative provisions was raised shortly after their entry into force. The Commissioner for Human Rights of the Russian Federation, the Foundation "Kostroma Center for Supporting Social Initiatives," and citizens L.G. Kuzmina, S.M. Smirensky and V.P. Yukechev appealed to the Constitutional Court of the Russian Federation on this issue.

The Constitutional Court, in its Ruling of 8 April 2014 No. 10-P in the case of checking the constitutionality of the provisions of part 6 of Article 2 and part 7 of Article 32 of the Federal Law on Non-Commercial Organizations, part 6 of Article 29 of the Federal Law on Public Associations and part 1 of Article 19.34 of the Code of Administrative Offences, in connection with the complaints of the Commissioner for Human Rights of the Russian Federation, the Foundation "Kostroma Center for Supporting Social Initiatives" and citizens L.G. Kuzmina, S.M. Smirensky and V.P. Yukechev, ${ }^{41}$ concluded that the contested provisions of the Federal Laws on Non-Commercial Organizations and on Public Associations are aimed at ensuring transparency of the activities of

39 Постановление Правительства Российской Федерации от 26 января 2017 г. № 89 «О реестре некоммерческих организаций - исполнителей общественно полезных услуг» // СПС «КонсультантПлюс» [Resolution of the Government of the Russian Federation No. 89 of 26 January 2017. On the Register of Non-Commercial Organizations-Performers of Socially Useful Services, SPS "ConsultantPlus"] (Jul 5, 2020), available at http://www.consultant.ru/document/cons_doc_LAW_211967/.

40 Федеральный закон от 23 мая 2015 г. № 129-Ф3 «О внесении изменений в отдельные законодательные акты Российской Федерации» // СПС «КонсультантПлюс» [Federal Law No. 129-FZ of 23 May 2015. On Amendments to Certain Legislative Acts of the Russian Federation, SPS "ConsultantPlus"] (Jul 5, 2020), available at http://www.consultant.ru/document/cons_doc_LAW_179979/.

41 Постановление Конституционного Суда Российской Федерации от 8 апреля 2014 г. № 10-П // СПС «КонсультантПлюс» [Resolution of the Constitutional Court of the Russian Federation of 8 April 2014 No. 10-P, SPS "ConsultantPlus"] (Jul 5, 2020), available at http://www.consultant.ru/document/ cons_doc_LAW_161690/. 
non-governmental non-profit organizations that are funded from foreign sources and are engaged in political activities on the territory of the Russian Federation. The Constitutional Court believes that these norms of federal laws do not prevent nongovernmental organizations from receiving foreign funding and using the funds received in political activities. When applying the impugned norms of federal laws, as the Constitutional Court points out, one should proceed from the presumption of legality and good faith in the activities of non-profits, which have the right to judicial protection against unreasonable claims of the governmental bodies of justice and the interior, as well as of prosecutors. At the same time, the Constitutional Court declared the norm of part 1 of Article 19.34 of the Code of the Russian Federation on Administrative Offenses, which stipulates liability for violation of the activities procedure of organizations performing the functions of a foreign agent, inconsistent with the Constitution. The norm, according to the position of the Constitutional Court, is unconstitutional since it does not allow the imposition of an administrative penalty below the lowest limit and the taking into account of the specific circumstances of the violation of the law.

However, the court did not come to a unanimous decision in this case. Judge V.G. Yaroslavtsev presented a dissenting opinion, ${ }^{42}$ according to which the challenged norms of the Federal Laws on Non-Commercial Organizations and on Public Associations do not correspond to a number of articles of the Constitution of the Russian Federation. Having studied Articles 13 (parts 1, 3 and 4), 30 (part 1) in conjunction with Articles 19 (part 1), 28, 29 (parts 1, 3 and 4), 31, 32 (part 1) and 33 of the Constitution of the Russian Federation, Judge Yaroslavtsev concluded that,

Non-profit organizations (including public associations) that receive funds from foreign sources have the right to participate in political activities under the same legal conditions, regardless of their attitude to decisions taken by public authorities and their policies.

\section{Legislation of the Constituent Entities of the Russian Federation}

Turning to paragraph " $b$ " of Article 72 (joint jurisdiction of the Russian Federation and its constituent entities) of the Constitution of the Russian Federation, one can conclude that the creation of an effective mechanism for protecting constitutional human rights in the territory of the constituent entities of the Russian Federation is one of the main tasks of regional legislation. In this regard, regional legal acts should aim at adjusting federal legislation to the specificity of each constituent entity of the Russian Federation in such a way that the protection of the rights and

42 Resolution of the Constitutional Court of the Russian Federation of 8 April 2014 No. 10-P, supra note 41. 
legitimate interests of persons and their associations registered in the territory of a particular region would be most adequate and complete. This especially applies to the problem of gaps in federal legislation, when the constituent entity needs to resolve certain issues, which contribute to the protection of rights or streamlining the activities of non-governmental organizations, but which are not reflected in other legal acts or federal laws.

In the 1990s, the constituent entities of the Russian Federation quite actively inserted provisions concerning not-for-profit organizations, including public associations, in their constitutions and charters, and adopted regional acts dedicated to non-profits. At the same time, the constituent entities endowed non-profit organizations with rights that they did not have at the federal level. For example, in many of the constituent entities public associations as a whole or their certain types have been empowered to initiate regional laws. There are also other features of establishing the status of public associations and other non-profit organizations at the level of the subjects of the Russian Federation at this first stage of development of regional legislation on non-profit organizations in modern Russia. The mentioned stage was characterized by a large number and great variety of laws and other legal acts approved in the constituent entities of the Russian Federation. Also adopted were regional laws and other acts on non-commercial organizations, charities, public associations, communities of small in number indigenous peoples, respective constituent entity governmental grants (to non-profits), social order, interaction between non-governmental organizations and constituent entity State bodies, tax benefits and exemptions at the constituent entity of the Russian Federation level (for charities or non-profits in general), etc. Of course, not all the constituent entities legislated on all of the mentioned issues. Some of them issued several acts in these spheres and some of them only one or two. One of the rarest fields of regulation was legislation on lobbying: for instance, the 1995 Krasnodar provincial Law on Law-Making and Legal Normative Acts of Krasnodar Province contained Chapter 7, entitled "Lobbyism in Law-Making in the Province,",43 and stipulated that lobbyists are representatives of public associations having lobbying accreditation with the provincial Parliament.

The majority of legal acts under consideration were adopted in the second half of the 1990s and in the beginning of the 2000s, but some of them were issued even before the 1993 Constitution of the Russian Federation took effect. For instance, in Moscow (as a constituent entity) the mayor issued the edict approving the Regulation on the Procedure of Non-Commercial Organizations Registration ${ }^{44}$ in 1992 and the

43 Правовые аспекты деятельности НКО юга России: анализ практики и рекомендации: сборник [Legal Aspects of NGOs in the South of Russia: An Analysis of Practice and Recommendations: Collection] 55-59 (Stavropol, 1999).

44 Правовой статус некоммерческих организаций в России: практическое пособие [Legal Status of Non-Commercial Organizations in Russia: Practical Guide] 201-208 (Moscow: Center for Democracy and International Charitable Foundation for Political and Legal Research "Interlegal," 1995). 
edict approving Provisional Regulation on Non-Governmental Non-Commercial Organizations $s^{45}$ on 30 April 1993, while the Russian Constitution did not came into effect until 25 December 1993. Though such acts entered into force earlier than the Constitution, they were modified in parallel with the drafting of the Constitution and all versions of the draft Constitution were well known by the general public. That is why the authors of such regional acts tried to elaborate them in consistency with the draft Constitution. In any case, legal acts that entered into force earlier than the Constitution had and have effect to the extent they fully or partially had or have no contradictions with the Constitution. This stage lasted from the beginning of the 1990 s to the middle of the first decade of the 2000s.

The second stage of development of regional legislation on non-profit organizations began in the first half of the first decade of this century and was characterized by a narrowing of the legislative regulation of non-profit organizations at the level of the constituent entities of the Russian Federation in connection with the struggle launched by the General Prosecutor's Office and its subordinate prosecutors all over the country against contradictions of regional legislation with federal norms. In the course of this struggle, a number of laws of the constituent entities were canceled due to their dissimilarity to certain federal laws or due to the absence of similar federal laws, although a number of regional laws proclaimed to be contrary to federal laws were adopted within the jurisdiction of the constituent entities and did not violate applicable federal legal provisions.

However, it turned out that it was impossible to resolve all the issues of the functioning of not-for-profit organizations exclusively at the federal level. Therefore, at the beginning of the second decade of this century, the third stage of development of the legislation of the constituent entities on non-profits began (and continues today), which is characterized by some expansion, although uneven from one constituent entity to another, of regional legislative regulation of non-profit organizations. But at this stage, in an effort to avoid accusations of contradictions with federal law, some of the articles of federal laws, unlike in the stage of the 1990s, are simply duplicated in regional laws, because a discrepancy between the wording of articles is treated by prosecution authorities and other federal bodies as a contradiction without deepening the study of texts of legislative acts.

If not so long ago the prevailing negative trend in the development of the regulatory framework at the regional level was a duplication at the regional level of federal legal norms - often leading to the fact of including in the laws of the constituent entities some provisions that are within the exclusive jurisdiction of the Russian Federation, which cannot be inserted in the laws of the constituent entities, and especially so if such provisions are not able to perform regulatory functions - and led, eventually, to the contradictions in the legal acts of different levels, in recent years there has been

45 Legal Status of Non-Commercial Organizations in Russia, supra note 44, at 208-212. 
a tendency to reduce the volume and scope of regional legal regulation, which has led, in turn, to the fact that many researchers note that regional legislation in most subjects of the Russian Federation is non-systemic and fragmented. ${ }^{46}$ This does not meet the requirements of the times, given the complexity of the development of civil society institutions in a protracted economic crisis, and generally difficult conditions for their formation and development.

In general, the legislative regulation of non-profits in the constituent entities of the Russian Federation is in line with federal legislation, which is quite natural and corresponds to the letter and spirit of the law. ${ }^{47}$ At the same time, a specific feature of legislative practice in the field of human rights protection, for example, as in many other areas related to the activities of public associations, is the desire to specify in detail almost all legal relations in these areas at the level of federal legislation, which inevitably narrows the regional legal space, but does not positively affect the quality of legal acts adopted in the regions. A number of legal scholars draw attention to this, noting a noticeable "contraction of lawmaking" in the regions. In turn, the limited scope of the legislation of the constituent entities may lead to a weakening of the initiative on their part in the development of the regional legal framework, thereby casting doubt on the federal nature of the State. ${ }^{48}$

It is clear that to a certain extent the federal legislation itself, fixing at the constitutional level the jurisdiction of the Russian Federation and the jurisdiction of its constituent entities, affects a certain narrowing of regional rulemaking. For example, the regulation of human rights is referred to the exclusive jurisdiction of federal law. Thus, the laws of the constituent entities of the Russian Federation regulating freedom of conscience, including the activities of religious associations, are valid only in nine constituent entities, similar regulatory acts were repealed in about twenty constituent entities, and new laws were not adopted. In about two dozen regions, laws in the field of volunteerism and charity were repealed in contrast to twenty-three constituent entities where such laws are still in force. One can mention regional laws on supporting horticultural, garden and suburban rest-

46 See Научные концепции развития российского законодательства [Scientific Concepts of Russian Legislation Development] (T.Ya. Khabrieva \& Yu.A. Tikhomirov (eds.), Moscow: Yurisprudentsiya, 2015).

47 See, e.g., Авакьян C.А. Политический плюрализм и общественные объединения в Российской Федерации: конституционно-правовые основы [Suren A. Avakian, Political Pluralism and Public Associations in the Russian Federation: Constitutional Legal Foundations] (Moscow: Russian Legal Publishing House, 1996); Малый Д.А. Конституционное право на объединение в Российской Федерации: вопросы теории и практики [Denis A. Maly, Constitutional Right to Association in the Russian Federation: Issues of Theory and Practice] (St. Petersburg: Yuridicheskiy tsentr Press, 2003); and others.

48 Хабриева Т.Я. Разграничение законодательной компетенции Российской Федерации и ее субъектов // Соотношение законодательства Российской Федерации и законодательства субъектов Российской Федерации [Taliya Ya. Khabrieva, Delimitation of the Legislative Competence of the Russian Federation and its Constituent Entities in Correlation of the Legislation of the Russian Federation and the Legislation of Constituent Entities of the Russian Federation] 102, 105 (T.Ya. Khabrieva (ed.), Moscow: Olita, 2003). 
house non-profit associations: in nine constituent entities they were repealed in contrast to seventeen constituent entities with their existing regional regulations.

There is the opinion that now,

The deepest crisis is undergoing regional lawmaking, in fact, it has been reduced to zero. ${ }^{49}$

And this despite the fact that the authorities in the constituent entities of the Russian Federation, in principle, aim at creating an integrated legal framework in regulating the activities of civil society institutions, in particular, the activities of regional non-governmental organizations, which is integral to and does not contradict federal legislation. There is awareness among regional authorities and civil society organizations that such a legal framework is necessary and very useful for them. Moreover, many constituent entities are trying to preserve and even develop areas of self-regulation that are important to them (which will be discussed later) and which is not easy at all, given the sometimes excessive regulatory impact of federal legislation in the area under consideration. In this regard, it should be said that the requirement of federal legislation is the need to constantly update existing rules and create new legal acts aimed at effective support in the regions of nongovernmental organizations, although this is very difficult to put into practice due to the large number of federal laws (related to various branches of law) that regulate the activities of public associations and other non-profits.

However, one has to admit that there are a lot of constituent entities of the Russian Federation where, on the contrary, they do not even accept laws whose necessity is directly enshrined in federal law. A number of Russian regions, as already noted,

use more flexible means during the period of legislative updates of various institutions: the adoption of other regulatory legal acts, individual decisions of executive authorities. ${ }^{50}$

This is largely due to the complexity noted earlier in developing their own legal acts that would take into account all the nuances of federal law and not contradict them.

49 Власенко Н.А. О кризисных тенденциях в праве // Юридическая техника. 2014. № 8. С. 42 [Nikolay A. Vlasenko, On the Crisis Trends in the Law, 8 Legal Technique 40, 42 (2014)].

50 Никитина E.E. Конституционно-правовое регулирование общественных объединений в Российской Федерации: региональный аспект // Журнал зарубежного законодательства и сравнительного правоведения. 2015. № 6(55). C. 968 [Elena E. Nikitina, Constitutional Legal Regulation of Public Associations in the Russian Federation: Regional Aspect, 6(55) Journal of Foreign Legislation and Comparative Law 966, 968 (2015)]. 
It is not surprising that often changing federal and regional legislation leads to confusion with laws, frequent collisions among laws, and difficulty in the application and enforcement of the law, which does not contribute to instilling citizens with lawobserving behavior and generally respecting legal norms and rules. Even when trying to comply with all legal norms it is easy to accidentally make a mistake somewhere. And the quality of legal training, which has decreased during the reform of Russian education, affects the potential of personnel as well as ultimately the newly adopted laws or amendments to acting laws. This refers to both the federal and the regional levels; in a number of regions, the shortage of highly qualified specialists is especially relevant.

The mobility of the normative framework for the regulation of the activities of non-profits entails a progressive increase in the number of regional laws in this area. Moreover, the updating of a regional regulatory act is mainly carried out through the adoption of a "new regulatory act without linking the latter with the current system of regional acts.".$^{151}$ That is why in many regions of the country there are several laws at once on the same subject of regulation, which is unacceptable. As an example, one can mention the institution of State financial support for the activities of nonprofits, primarily charitable organizations.

Let us emphasize that the regional legal acts are nowadays devoted mainly to various aspects of State support for the activities of non-governmental organizations by the authorities of the constituent entities of the Russian Federation. As noted in one of the studies, the analysis of regional regulation clearly indicates this fact. Thus the very concept of "State support" is used in the name of regional laws on State support for citizens' participation in public order protection in 78 constituent entities; on voluntary fire protection groups, in 74 entities; support for socially oriented nonprofit public associations, in 54 entities; youth and children's public associations, in about 30 entities; charity and volunteerism, in 23 entities; horticultural, gardening and suburban rest-house non-profit associations, in 17 entities; trade unions, in 15 entities; and the interaction of public authorities of a particular constituent entity and public associations, in 12 entities of the Russian Federation. In addition, issues of State support to certain types of public associations are regulated at the regional level, in particular, associations of veterans (in 5 constituent entities of the Russian Federation), disabled people (in 10), Cossacks (in 33) as well as national-cultural autonomies (in 13), and creative unions (in 2). ${ }^{52}$ For example, certain constituent entities have their own laws on creative unions: the 1998 Bashkortostan Law on Creative Workers and Creative Unions in the Republic of Baskortostan ${ }^{53}$ and the 2002

51 Nikitina 2015, at 969.

52 Id. at 968 .

53 Закон Республики Башкортостан от 25 ноября 1998 г. № 191-з «О творческих работниках и творческих союзах в Республике Башкортостан» [Law of the Republic of Bashkortostan No. 191-z 
Kabardino-Balkaria's Law on Creative Workers and Creative Unions of the Cultural Sphere of the Kabardino-Balkarian Republic. ${ }^{54}$

Certainly, the above quantitative data change over time, since it is difficult even for specialists to keep track of rapidly transforming regional legislation, and it is not always clear whether a number of laws of the constituent entities of the Russian Federation that amend existing laws and those that regulate several areas should be included in these statistics (and in which section, if included). Here one can mention the 2004 Law of the Tyumen Region on State Support of National-Cultural Autonomies and Other Public Associations in the Tyumen Region. ${ }^{55}$ It is not entirely clear with regard to those regional laws which, though they relate to a particular issue of the activities of non-governmental organizations, do not regulate a certain sphere of legal relations: for example, the 2015 Law of the Ulyanovsk Region on the Definition of Territories for the Implementation of Agricultural Production, Preservation and Development of Traditional Lifestyles and Management of Land Plots that Are in State or Municipal Ownership, Provided to Individual Cossack Partnerships on the Basis of Lease Agreements Concluded Without Bidding.$^{56}$ There are many examples of such laws in Russian regions.

In general, the lack of a systemic character is, unfortunately, a characteristic feature of Russian legislation in the area under consideration, especially at the regional level, since the subjects not only absorbed the shortcomings of imperfect federal legislation, but also spawned their own. In particular, in a number of constituent entities of the Russian Federation several laws have been adopted regarding the

of 25 November 1998. On Creative Workers and Creative Unions in the Republic of Baskortostan] (Jul 5, 2020), available at http://www.docs.cntd.ru/document/935102923.

54 Закон Кабардино-Балкарской Республики от 23 января 2002 г. № 5-Р3 «О творческих работниках и творческих союзах сферы культуры Кабардино-Балкарской Республики» // СПС «Гарант» [Law of the Kabardino-Balkarian Republic No. 5-RZ of 23 January 2002. On Creative Workers and Creative Unions of the Cultural Sphere of the Kabardino-Balkarian Republic, SPS "Garant"] (Jul 5, 2020), available at https://base.garant.ru/30500840/.

55 Закон Тюменской области от 28 декабря 2004 г. № 315 «О государственной поддержке национально-культурных автономий и иных общественных объединений в Тюменской области» // СПС «Гарант» [Law of the Tyumen Region No. 315 of 28 December 2004. On State Support of National-Cultural Autonomies and Other Public Associations in the Tyumen Region, SPS "Garant"] (Jul 5, 2020), available at https://base.garant.ru/18714640/.

56 Закон Ульяновской области от 3 июля 2015 г. № 83-30 «Об определении территорий, для осуществления на которых сельскохозяйственного производства, сохранения и развития традиционного образа жизни и хозяйствования земельные участки, находящиеся в государственной или муниципальной собственности, предоставляются отдельным казачьим обществам на основании договоров аренды, заключаемых без проведения торгов» // CПC «Гарант» [Law of the Ulyanovsk Region No. 83-ZO of 3 July 2015. On the Definition of Territories for the Implementation of Agricultural Production, Preservation and Development of Traditional Lifestyles and Management of Land Plots that Are in State or Municipal Ownership, Provided to Individual Cossack Partnerships on the Basis of Lease Agreements Concluded Without Bidding, SPS "Garant"] (Jul 5, 2020), available at https://base.garant.ru/15350709/. 
issue of regulating support for non-governmental organizations, which can hardly be called good practice. As an example, one can cite the Laws of the Vologda Region of 2010 on the Division of Powers Between Regional State Authorities to Address Issues of Support for Socially Oriented Non-Profit Organizations ${ }^{57}$ and of 2013 on State Support for Socially Oriented Non-Profit Organizations in the Vologda Region..$^{5}$ The first of these contains three articles and the second has eight. The content of both laws could well be combined in one document.

Article 4 of the 1999 Law of the Samara Region No. 18-DG ${ }^{59}$ provides the same list of "socially significant goals of charitable activities" as the federal legislation on charitable activities (in fact, this is the name of Article 4 of the regional law). And in Article 4 of the 2009 Law of the Krasnoyarsk Province on Charitable Activity in the Krasnoyarsk Province (entitled in 2019: on Charitable Activity and Volunteering in the Krasnoyarsk Province) ${ }^{60}$ a provision is established according to which

the following areas of charitable assistance to public organizations providing social organizations, which themselves provide priority charity assistance, are constant social assistance to orphans, children with disabilities and public organizations of persons with disabilities.

Obviously, such a rigid list of types of assistance, which serve as the basis for support from the State, limits the possibilities of charities to develop initiatives to provide assistance to those in need, and even more complicates the lives of those to whom such assistance is extremely important. But in this case, regional legislators followed the path trodden by federal legislators, without contradicting federal law.

57 Закон Вологодской области от 1 ноября 2010 г. № 2391-О3 «О разграничении полномочий между органами государственной власти области по решению вопросов поддержки социально ориентированных некоммерческих организаций» [Law of the Vologda Region No. 2391-OZ of 1 November 2010. On the Division of Powers Between Regional State Authorities to Address Issues of Support for Socially Oriented Non-Profit Organizations] (Jul 5, 2020), available at http://docs.cntd. ru/document/460302085.

Закон Вологодской области от 18 октября 2013 г. № 3184-О3 «О государственной поддержке социально ориентированных некоммерческих организаций в Вологодской области» // СПС «Гарант» [Law of the Vologda Region No. 3184-OZ of 18 October 2013. On State Support for Socially Oriented Non-Profit Organizations in the Vologda Region, SPS "Garant"] (Jul 5, 2020), available at https://base.garant.ru/20409102/.

59 Закон Самарской области от 24 мая 1999 г. № 18-ГД «О благотворительной деятельности в Самарской области» // СПС «Гарант» [Law of the Samara Region No. 18-GD of 24 May 1999. On Charitable Activities in the Samara Region, SPS "Garant"] (Jul 5, 2020), available at https://base.garant.ru/8306443/.

60 Закон Красноярского края от 12 ноября 2009 г. № 9-3962 «О благотворительной деятельности и добровольчестве (волонтерстве) в Красноярском крае» [Law of the Krasnoyarsk Territory No. 9-3962 of 12 November 2009. On Charitable Activity in the Krasnoyarsk Province] (Jul 5, 2020), available at http://docs2.cntd.ru/document/985017240. 
One of the subject matters of regulation by regional legislation is the ways, means and procedures for interaction with public authorities and support for public associations in the constituent entities of the Russian Federation. Regional legislation in these fields partially duplicates federal laws, and at the same time many constituent entities develop their own methods of regulation, which raises the question of systematization of legislation once more.

And in this regard, there are examples of success in regional law-making, but there are not as many as one would like to have. Thus, in Russian regions, after the adoption of the 2011 Federal Law on Voluntary Fire Protection, ${ }^{61}$ laws began to appear on the regulation of voluntary fire protection, while almost all the constituent entities of the Russian Federation already had laws on fire safety, in accordance with Article 18 of the 1994 Federal Law on Fire Safety. ${ }^{62}$ So it was quite possible to avoid a quantitative increase in the regulatory framework in the constituent entities if regions proceeded by amending the legislation already in force. This was done, for example, by the legislators of the Nizhny Novgorod region when they amended the 1995 Law of the Nizhny Novgorod Region on Fire Safety, ${ }^{63}$ which combined various issues of fire protection regulation, including voluntary fire protection. In the Ulyanovsk region, after the adoption of federal legislation on support for socially oriented non-commercial organizations, a separate law was not also passed, and on 9 November 2010 the Law on Amendments to Certain Legislative Acts of the Ulyanovsk Region on the Issue of Support for Socially Oriented Non-Commercial Organizations ${ }^{64}$ was adopted.

Speaking of the problem of duplication of normative acts, it is worth touching on such an aspect as the reluctance in many constituent entities of the Russian Federation to take legislative initiative where federal legislation does not impede doing so. For example, the Federal Law on Non-Commercial Organizations, in particular Article 31, does not prohibit them from deciding for themselves what types of non-governmental activities may receive support from regional and local

61 Федеральный закон от 6 мая 2011 г. № 100-Ф3 «О добровольной пожарной охране» // СПС «КонсультантПлюс» [Federal Law No. 100-FZ of 6 May 2011. On Voluntary Fire Protection, SPS “ConsultantPlus"] (Jul 5, 2020), available at http://www.consultant.ru/document/cons_doc_LAW_113763/.

62 Федеральный закон от 21 декабря 1994 г. № 69-Ф3 «О пожарной безопасности» // СПС «КонсультантПлюс» [Federal Law No. 69-FZ of 21 December 1994. On Fire Safety, SPS “ConsultantPlus"] (Jul 5, 2020), available at http://www.consultant.ru/document/cons_doc_LAW_5438/.

63 Закон Нижегородской области от 26 октября 1995 г. № 16-3 «О пожарной безопасности» // СПС «Гарант» [Law of the Nizhny Novgorod Region No. 16-Z of 26 October 1995. On Fire Safety, SPS "Garant"] (Jul 5, 2020), available at https://base.garant.ru/8595178/.

64 Закон Ульяновской области от 9 ноября 2010 г. № 181-30 «О внесении изменений в отдельные законодательные акты Ульяновской области по вопросу поддержки социально ориентированных некоммерческих организаций» // СПС «Гарант» [Law of the Ulyanovsk Region No. 181-ZO of 9 November 2010. On Amendments to Certain Legislative Acts of the Ulyanovsk Region on the Issue of Support for Socially Oriented Non-Commercial Organizations, SPS "Garant"] (Jul 5, 2020), available at https://base.garant.ru/15325777/. 
authorities. Part 2 (paragraph 3) of Article 31 of the Federal Law even stipulates the issue of expanding the activities of non-governmental organizations aimed at solving social problems and developing civil society that can receive such support. Nevertheless, the regions rarely use their right to expand the list of those areas of non-governmental organizations' activity that can be supported locally. There are many regional laws that simply list the types of activities that the federal law contains, although this will further complicate not only the work of regional nongovernmental organizations, but also the work of the legislators themselves, since the regional list will have to be constantly monitored and supplemented after the federal list. Not to mention the fact that which areas of non-governmental organizations' activity are most in demand by the population of a particular region is more visible in the localities. Of the positive examples in regional legislation that takes into account the specifics of the region, one can mention such laws as the 2012 Law of the Murmansk Region on State Support of Socially Oriented Non-Commercial Organizations in the Murmansk Region ${ }^{65}$ and the 2011 Karelia Law on State Support of Socially Oriented Non-Commercial Organizations in the Republic of Karelia. ${ }^{66}$ In the former, the list indicated the activities for organizing the mediation procedure; the latter indicated the perpetuation of the memory of local famous compatriots and other prominent citizens associated with the region.

Nevertheless, it still must be said that at the federal level officials are aware of the existing problems of legislation, the need for reasonable unification and systematization of regional legislation, and that model acts of laws were developed by federal ministries and departments which became the prototype of a number of regional regulatory legal acts. At the same time, the existing flaws in federal model laws (e.g. the law on State support for socially oriented non-commercial organizations) were embodied in many laws of a similar orientation at the regional level. In particular, many problems have arisen in regional legislation on the principles of interaction between government bodies of the constituent entities of the Russian Federation and non-profits. As E. Nikitina rightly notes in her research, the term "basic principles" was misinterpreted, although the relevant chapter dealt with specific legal norms. An example is given with the Law of the Nizhny Novgorod Region of 7 May 2009 No. 52-Z on State Support of Socially Oriented Non-Commercial Organizations

65 Закон Мурманской области от 5 марта 2012 г. № 1450-01-3МО «О государственной поддержке социально ориентированных некоммерческих организаций в Мурманской области» [Law of the Murmansk Region No. 1450-01-ZMO of 5 March 2012. On State Support of Socially Oriented Non-Commercial Organizations in the Murmansk Region] (Jul 5, 2020), available at http://www.docs. cntd.ru/document/913522450.

Закон Республики Карелия от 5 декабря 2011 г. № 1562-3РК «О поддержке социально ориентированных некоммерческих организаций в Республике Карелия» // CПС «Гарант» [Law of the Republic of Karelia No. 1562-ZRK of 5 December 2011. On State Support of Socially Oriented NonCommercial Organizations in the Republic of Karelia, SPS "Garant"] (Jul 5, 2020), available at https:// base.garant.ru/23111501/. 
in the Nizhny Novgorod Region, in which some provisions are redundant, the wording is too detailed (e.g. one could briefly summarize the principle of mutual non-interference), and "the mention of an exception to the General rule makes the formulation of the principle a separate specific norm." ${ }^{167}$ A similar norm exists in Article 3 of the 2013 Law on State Support of Socially Oriented Non-Profit Organizations in the Republic of Dagestan, ${ }^{68}$ in which the principles include the provision "Mutual Control," and the forms, procedure, subject to control by State bodies are formulated as a specific norm. Moreover, many regional laws do not rely on the indicated norm of the model law, and therefore the principles of interaction are more accurately formulated in them. Examples here are Article 4 of the 2013 Law on State Support of Socially Oriented Non-Commercial Organizations in the Krasnoyarsk Province ${ }^{69}$ and Article 2 of the 2010 Law on State Support of Socially Oriented Non-Commercial Organizations in the Trans-Baikal Province. ${ }^{70}$

It should be considered redundant in the legislation of the constituent entities of the Russian Federation to include in laws which specify the norms of federal laws the notions and terms used if the legislation does not deal with new notions used in the region (e.g. a "governor's grant"). Thus, in Article 2 of the 2012 Law on State Support of Socially Oriented Non-Commercial Organizations in the Ryazan Region there is a reference norm which states that,

The basic concepts and terms in this Law are used in the same meaning as in the Federal Law on Non-Commercial Organizations. ${ }^{71}$

67 Nikitina 2015, at 971.

68 Закон Республики Дагестан от 30 декабря 2013 г. № 105 «О государственной поддержке социально ориентированных некоммерческих организаций в Республике Дагестан» // СПС «Гарант» [Law of the Republic of Dagestan No. 105 of 30 December 2013. State Support of Socially Oriented Non-Profit Organizations in the Republic of Dagestan, SPS "Garant"] (Jul 5, 2020), available at https:// base.garant.ru/26579839/.

69 Закон Красноярского края от 7 февраля 2013 г. № 4-1041 «О государственной поддержке социально ориентированных некоммерческих организаций в Красноярском крае» [Law of the Krasnoyarsk Territory No. 4-1041 of 7 February 2013. On State Support of Socially Oriented Non-Commercial Organizations in the Krasnoyarsk Province] (Jul 5, 2020), available at http://docs.cntd.ru/ document/465801455.

70 Закон Забайкальского края от 24 ноября 2010 г. № 432-33К «О государственной поддержке социально ориентированных некоммерческих организаций в Забайкальском крае» // СПС «Гарант» [Law of the Trans-Baikal Territory No. 432-ZZK of 24 November 2010. On State Support of Socially Oriented Non-Commercial Organizations in the Trans-Baikal Province, SPS "Garant"] (Jul 5, 2020), available at https://base.garant.ru/19923183/.

71 Закон Рязанской области от 9 ноября 2012 г. № 86-оз «О государственной поддержке социально ориентированных некоммерческих организаций в Рязанской области» [Law of the Ryazan Region No. 86-oz of 9 November 2012. On State Support of Socially Oriented Non-Profit Organizations in the Ryazan Region] (Jul 5, 2020), available at http://docs.cntd.ru/document/453357366. 
However, the terms and notions used are contained not only in that law, but also in other federal laws.

The streamlining and systematization of legislation in this area is still waiting in the wings.

\section{References}

Власенко Н.А. О кризисных тенденциях в праве // Юридическая техника. 2014. № 8. C. 40-45 [Vlasenko N.A. On the Crisis Trends in the Law, 8 Legal Technique 40 (2014)].

Малый Д.А. Конституционное право на объединение в Российской Федерации: вопросы теории и практики [Maly D.A. Constitutional Right to Association in the Russian Federation: Issues of Theory and Practice] (St. Petersburg: Yuridicheskiy tsentr Press, 2003).

Freedom of Association: Digest of Decisions and Principles of the Freedom of Association Committee of the Governing Body of the ILO ( $4^{\text {th }}$ ed., Geneva: ILO, 1996).

The Palgrave Handbook of Volunteering, Civic Participation, and Nonprofit Associations (D.H. Smith et al. (eds.), Basingstoke: Palgrave Macmillan, 2016).

\section{Information about the authors}

Alexei Avtonomov (Moscow, Russia) - Vice-Rector of the Institute of International Law and Economics named after A. Griboedov (10 Masterkova St., Moscow, 115280, Russia; e-mail: a.s.avtonomov@yandex.ru).

Vladislav Grib (Moscow, Russia) - Head of the Department of Legal Foundations of Governance, MGIMO University (14 Novokonyushenny pereulok, Moscow, 119121, Russia; e-mail: ispolkom@lawinfo.ru). 